\title{
UNIVERSITYOF
}

FORWARD

THINKING

WESTMINSTER用

WestminsterResearch

http://www.westminster.ac.uk/westminsterresearch

A comparative political economy of regional migration and labour mobility in West and Southern Africa

Cross, $\mathrm{H}$. and Cliffe, Lionel

This is an Accepted Manuscript of an article published by Taylor \& Francis in Review of African Political Economy, DOI: 10.1080/03056244.2017.1333411.

The final definitive version is available online:

https://dx.doi.org/10.1080/03056244.2017.1333411

(C) 2017 Taylor \& Francis

The WestminsterResearch online digital archive at the University of Westminster aims to make the research output of the University available to a wider audience. Copyright and Moral Rights remain with the authors and/or copyright owners.

Whilst further distribution of specific materials from within this archive is forbidden, you may freely distribute the URL of WestminsterResearch: ((http://westminsterresearch.wmin.ac.uk/).

In case of abuse or copyright appearing without permission e-mail repository@westminster.ac.uk 


\section{A comparative political economy of regional migration and labour mobility in West and Southern Africa}

\section{Introduction}

By the summer of 2013, towards the end of his life, Lionel Cliffe and I had mapped out this article and had organised it into methodological and theoretical areas, with the inclusion of a reading list. It is based on a collaboration and dialogue about regional labour migration flows in West and Southern Africa. ${ }^{1}$ We asked if, and how, we could document and seek to explain the dynamics of appreciable continuities and discontinuities with established regimes of labour mobility, and how this is useful for understanding contemporary realities. We were exploring to what extent we can categorise distinct patterns of migration in our respective regions of interest and seeking what is common in their modes of analysis.

At the core of this dialogue was the recognition of migrants in communities as agents who are taking actions, but avoidance of the discussion of motives and household strategies; instead considering that actions are pursued under specific contexts. As O’Laughlin (1999, pp. 23-24) puts it: 'the notion that agency is best understood through the individual models of decision rather than analysis of dialectical structure is one of the most suasive and enduring fallacies in contemporary social thought' - instead, the focus should be on the kind of dynamic structural model that explains the social shaping of agency. In locating local communities in regional patterns and in global processes, this article adopts a political economy perspective on different scales of analysis. It makes no attempt to extract a single theory of the political economy of migration but it suggests agendas and methods for approaching contemporary patterns. In doing this, we can develop an understanding of how labour movement defines the region, and how Africa fits in the global economy of labour mobility.

There are two key organising concepts for this article: firstly the regionalisation of Africa, as outlined by Samir Amin (1972; 1995; Amin and Bush 2014), with the aim to question in particular the paradigms of 'Africa of the labour reserves' and 'Africa of the colonial economy'. Secondly, we explore the mechanisms and characteristics of cheap labour on different scales of analysis. This includes an outline and discussion of the models that explored the underlying accumulation processes and the relations of reproduction of labour within the system, and the reproduction of the system as a whole (Wolpe 1972, 1980; Meillassoux 1978a,b; Mafeje 1981). In doing so, we will indicate how the 'modes of production' discourse can bring focus not only to the production of material objects and to the extraction of material surplus between classes, but also to the production of people and social relations (Graeber 2006, p. 69, 77). While arguing that this long-abandoned theory is flawed and underdeveloped, especially in its conception of materialism, Graeber (2006, p.

\footnotetext{
${ }^{1}$ Presented at ASAUK annual conference, University of Leeds, 6-8 September 2012. See a tribute to Lionel Cliffe here: http://lucas.leeds.ac.uk/tribute/lionel-cliffe-1936-2013/
} 
66-9) suggests its reconsideration because he associates its demise with the naturalisation of capitalism. This is a trend that sees capitalism everywhere and as old as civilisation, existing where there is a market and therefore rendering useless the comparison of societies. The understanding that instead, capitalism is not a neat, linear or universal process (as highlighted in Amin 1972, pp. 506-7; Mafeje 1981, p. 137; Arrighi 1970, p. 199; Klein 1985, p. 10) is essential to a fresh reading of literature that has been characterised as divorced from context and overly abstracted (these tensions are played out in Freund 1985, p. 27; Klein 1985, p. 12; Coquery-Vidrovitch 1985). It is a radical approach that was pioneered by activist scholars who joined the struggle of the societies they were researching.

In this perspective, this article examines two distinct regions, with different and changing dynamics which have, however, experienced terrible events in recent years that were exceptional only in scale and are related to some degree to their migrant labour systems, calling for renewed analytical tools. First, the massacre of 34 miners in Marikana in August 2012 re-awakened discussions of migrant labour and social reproduction in South Africa; and second in April 2015, a boat capsized north of Libya, killing over 800 including people from West Africa alongside the larger number of refugees. This and other almost daily disasters in the Mediterranean represent a regional crisis of labour as well as a refugee crisis.

\section{Regionalisation and migration patterns}

In Samir Amin's (1972) article on Underdevelopment and Dependence in Black Africa, three macro regions were identified between the extremes of African unity and up to 200 micro-regions that cross state frontiers. West Africa is described as 'Africa of the colonial trade economy (l'économie de traite)', the Congo River Basin as 'Africa of the concession-owning companies', and the eastern and southern parts of the continent as 'Africa of the labour reserves' (ibid., p. 504). These regional distinctions are based on the effects of colonialism, which intensified the forms of dependence established by mercantilism. There is a periodisation structuring Amin's article, moving from the pre-mercantilist period up to the period of colonisation. The concern is to study 'how the dialectic reveals itself between the major colonial policies and the structures inherited from the past' (ibid., p. 505).

In this analysis, the mobility of labour was central to West and Southern Africa's regional patterns of colonial development, while in the Congo River Basin, the colonial economy was based on plunder, coercing local societies into a vicious labour regime that many resisted by escaping. The complex social structures and hierarchisations developed in the slave trade in West Africa shaped a system of large-scale agricultural production for export. It incorporated an interior region that would transfer migrant labour to the wealthier coastal region. In Eastern and Southern Africa, mineral wealth and settler agriculture led the colonisers to drive rural communities into small, poor regions, creating so-called 'traditional' societies, 'with no means of modernising and intensifying their farming', thereby forcing them to supply temporary or permanent migrants on a vast scale (Amin 1972, p. 519).

In 1995, Amin returned to his regionalisations in a chapter that was explicitly focused on migration patterns and highlighted their 'extraordinary scope'. This is not because the redistribution of populations forms 'part of a process of accelerated industrialisation' as many 
of his contemporaries assumed - instead it has a close relation to the peripheralisation created by the system of global capitalism and incorporates labour mobility within Africa in that structure (Amin 1995, p. 37). Also challenging the perspective of developmental models that suggested 'short-term migration by lone, male, rurally-based migrants [that] gradually gave way to "permanently urbanised”, "fully proletarianised”, settled urban working class', Ferguson (1990, p. 385) presented a more complex picture of migration in the Zambian Copperbelt. More recently and in a far-reaching study of Africa's regions, Potts (2010, p. 2021) similarly found the linearity of migrations to be a myth, with counter-urbanising trends and circular movements continuing in importance.

Amin again revisited the regional patterns in 2014 (Amin and Bush 2014) in a broader discussion about the challenges faced by Africa today. He highlights types of continuity and change; firstly that l'économie de traite remains predominant in West Africa, producing coffee, cocoa, palm oil and other commodities. He argues that this has now expanded into most of East Africa, with the relative replacement of the European white settlers by new African landlords; and also into Zimbabwe, Angola and Mozambique.

Studies of West African migration patterns today tend to focus on socio-cultural drivers of migration and the social and economic advantages that emerge, including the development capacity of remittance funds. Coercive patterns of labour migration were not widely institutionalised and ended earlier than in southern Africa (Potts 2010, pp. 40-42; Cross 2013, p. 15). However, the underlying patterns of trade that generated labour migration dynamics have persisted. Economists and scholars in Senegal highlight the significance of the macroeconomic level, by which the financialised monetary union of the franc zone, and more precisely its inflation targeting and peg to the euro, sustains a reliance on the foreign exchange reserves gained by exporting agricultural and raw materials to import essential food products, thereby maintaining a pattern of dependency (Nubukpo 2010, p. 360). That Ivory Coast, Ghana, Nigeria and Gambia have higher urban populations and are the only West African countries to have net immigration also indicates more continuity than change in economic geography (Devillard et al. 2015, p. 25). As Amin predicted, so-called 'traditional' and 'modern' sectors remain, with a surplus of labour in the former and inevitable household or individual decisions therein to diversify revenues through the migration of one or more members. The articulation of capitalist relations of production through large-scale dispossessions did not pave the way for modern capitalist societies of free labour; instead, contemporary flows replicate colonial movements towards coastal areas, which have themselves become key sources of emigration post-structural adjustment.

Official figures (which are likely to miss some circular and temporary patterns of migration) show that for Benin, Burkina Faso, Ivory Coast, Ghana, Guinea, Liberia, Mali, Niger, Senegal, Sierra Leone and Togo, primary destinations are predominantly neighbouring or nearby countries. For Gambia, Cape Verde, Guinea-Bissau and Nigeria, primary destinations are in Europe and the US (Devillard et al. 2015, p. 26). The migrant labour system in West Africa has diversified routes into North Africa, Europe and North America (Fall and Cissé 2007; Cross 2013). Migrations into Europe, with few legal channels, carry a high rate of failure but their historical importance and the relative gains from remittances in Euros mean they tend to overshadow the more common types of migration in local narratives. In our dialogue, we recognised these migrations as an extension and consequence of existing 
patterns of migrant labour, with the European Union partially acting as a supra-state in regulation of the regime.

Considering contemporary South Africa, Amin (Amin and Bush 2014, p. S110-111) notes the development of industry for the internal market, yet in spite of political change, the reserve economy, underpinned by the distribution of private property, has persisted. The contemporary patterns of migration within South Africa and some of the other countries of the region are understandably seen as significantly, though not entirely permanently, shaped by the apartheid system that developed in the 20th century, and in its parallels in colonial territories. The twentieth century pattern was characterised by a genuinely regional dimension, whereby migrant flows were in part formally structured across borders. Some countries, centrally South Africa, but including Zambia and Zimbabwe were net recipients, while other countries were definitely net suppliers of labour. It was theorised as essentially a 'system for reproducing cheap labour' (see Wolpe 1972, Mafeje 1981, Meillassoux 1981, Terray 1984, Rey 1975) - a paradigm that has been contested however, in terms of its empirical basis then and in the post-apartheid context.

The existence of flows within and beyond territorial borders that did not correspond to this sometimes too neat theorising need to be recognised. Moreover, while migration remains central to the regional political economy, there are major changes in the inherited patterns in this century and more volume, dynamism, and complexity has been observed (Crush and Williams 2010, p. 3; Reitzes 2000, p. 2). Botswana, Namibia and South Africa are the major destination countries, with little, if any, involvement from Botswana in the migrant labour system feeding into South Africa's mines and farms. There is less official recruitment of mine labour into South Africa from Malawi, Lesotho and Mozambique but more widespread and unofficial pan-African immigration. The collapse of Zimbabwe's economy transformed it from a net recipient to a massive exporter of labour to South Africa, Botswana and elsewhere in increasingly irregular forms. In-migration flows to Zimbabwe from Mozambique and Malawi, formerly central to past patterns, have shrunk and Mozambique is receiving migrants, unheard of in the past. There has been a partial reversal of rural-to-urban labour in Zambia since the 1970s (Potts 2010, p. 19). Movement between urban areas is significant in the region, and there are major flows into Johannesburg, previously discouraged under apartheid. Within Lesotho, female labour in the textile industry has changed internal patterns of migration (Baylies and Wright 1993). Commercial farming is another major sector to employ migrants, on corporate permits, especially in South Africa's border areas with Mozambique, Zimbabwe and Lesotho (Crush and Williams 2010, p. 12; Bolt 2015).

\section{Migrant labour and the modes of production discourse}

Having outlined the regional dynamics of labour migration, this section turns to the political economy of the reproduction of migrant labour. We consider different elements in the reproduction of that system - i.e. the whole set of relations of production and reproduction (and its possible breakdown) and their complex articulation. Cliffe (2011, unpublished paper) 
revisited the modes of production discourse in Southern Africa at a Festschrift in honour of Archie Mafeje, showing how it explored the dynamics of capital not just in the form of trade and investment but also in terms of social relationships. Some of this discussion is reproduced in this section, and it is worth doing so at length. A core insight from this approach was to show how enforced, temporary migrant labour is essentially cheap labour, and cheapener of labour power in general. Meanwhile, and contributing to this pattern, articulation theory ultimately recognised that in contrast to the orthodox Marxist understanding, capitalist contact with the non-European world does not immediately and completely commoditise labour, land and other resources, but instead operates with them as it finds them and relies on the peasant economy to support workers' families (Legassick 1974, pp. 266-8; Wolpe 1972, p. 436; Arrighi 1970, p. 206-7).

Mafeje's (1981) review of articulation theory pointed to the need to absorb the work of Claude Meillassoux, both as offering a framework for understanding pre-colonial social formations and for his insights into the nature of apartheid and its impoverishing impact on South Africa. This work made possible the reinterpretation or 'contextualising' of the vast portfolio of anthropological fieldwork, allowing the analysis of a changing but specific social formation.

At the same time, such analyses of 'pre-capitalist' social formations, when viewed in a comparative framework, raise issues as to the relative ease or difficulty of transformation of African social formations: did they share the allegedly 'static' characteristics of the 'Asiatic mode of production'? Did they have features that would facilitate or be resistant to the capitalist incursion and transition? But also, the insights offered by these perspectives on the pre-capitalist phase of African history came to be valued by a growing number of scholars concerned with contemporary Africa. Whether or not they see those indigenous forms as having been 'conserved', and whether or not they operate with a theoretical framework that views the present conjuncture as an 'articulation' of those preexisting modes of production with capitalism, many recognise that present African realities are not simply the product of the total elimination of all vestiges of the pre-existing society and their replacement by a fully-fledged and unadulterated capitalism, as was largely the case in the slave based and settler societies of North America or Australia. Instead there was recognition that the social relationships, their forms and the classes that confront each other, are not those of the 'pure' form of the capitalist mode of production: especially the core relationship did not consist of 'free' wage labour exploited by industrial or agrarian capital. Labour was found and taken on in different forms, many of which persisted and had their own dynamic.

One strand of analysis by Meillassoux (1981) stressed basic characteristics relevant to the social relationships within which land is embedded. He examined the fundamental subsistence-producing unit within an economy based on the exploitation of land by a lineage group, using simple technology and largely human power to produce their own subsistence. But in tracing the exchange of goods within this unit and between units, he stressed the mechanisms whereby this simple 'economy' reproduced itself. Essential to this process was the securing of future labour by the lineage unit, which was achieved by exchange not of subsistence, but of prestige goods, particularly in order to seal a marriage bond. Labour of women and of younger men was ensured thereby, but those who controlled the exchange of 
prestige goods and the whole process of marriage, the elders, also in the process ensured their dominance over both junior men and women. This lineage unit of production was thus characterised by antagonist contradictions between these groups.

This approach must thus be used to embrace 'not only the creation of use-values necessary to the life of the society, but also to the maintenance and consolidation of the social relations through which this creation is carried out' (Terray 1984, p.90). Terray (ibid. p. 91) goes on to admit that 'by not having taken (this) perspective of reproduction' into account he had not given sufficient weight the 'relations of production' to suggest it allows an understanding of the notion of one mode of production 'motivating' other(s) in a social formation: it is dominant 'when it subjects the functioning of other modes of production ... to the requirements of its own reproduction'. Meillassoux went on to give further emphasis to the 'perspective of reproduction' by showing that in the lineage based social formation, which he sees as so characteristic of Africa, the requirements of reproduction, specifically the exchange of women and their capacity for labour and physical reproduction, presupposes 'a clustering of the individual, (familial) productive cells and alliances between them ...'. Thus he argues: 'if there is to be a 'mode of production', it is here, in this gathering of productive units, organised for reproduction, that it is to be found' (1981, pp. 13-14).

Important and novel as the emphasis on the relations of production and especially of reproduction within the 'subsistence producing community' undoubtedly is, there is a danger in taking it for a model of the 'typical' pre-colonial social formation in Africa. It does illuminate the sphere of kinship in a materialist way and also the linkages between processes of reproduction and broader social processes. But it is precisely in the conclusion that the domestic community, with 'its ability to produce and reproduce itself' can offer a basis for reproducing labour in all class based economic systems, that it may be an incomplete way of characterising African social formations many of which had complex structures and superstructures other than simply an amalgam of lineages that exchanged their women (Meillassoux 1981, p. 87). (However, it might provide a point of entry to analysis of reproduction of labour in settler agriculture.) In short their work forces us to bring in the analysis of kinship and in turn culture, as Mafeje aimed to do, as a central focus of the analysis of social wholes, rather than to leave a dualism, to see two essentially unconnected levels (capitalism and patriarchy, for instance).

Most analysts recognised that pre-colonial Africa cannot be characterised in terms of the existence or even predominance of any single stage or mode of production, and many writings came to combine the approaches of Amin, with his 'tributary' emphasis, and the 'lineage' theorists, employing both concepts and conceptualising social formations in terms of one or other, in a structural 'articulation' rather than one over time. Amin (1972, p. 506507) emphasises that 'a society cannot be reduced to a mode of production' because this is an abstract concept, which does not incorporate a fixed historical sequence, while social formations are concrete structures, 'organised and characterised by a dominant mode of production which forms the apex of a complex set of subordinate modes', or 'a combination of modes of production' (Mafeje 1981, p. 133). Therefore, analogies cannot be drawn neatly between the same mode of production, belonging to societies of different ages.

But how then to use such perspectives to understand the dynamics of change? Meillassoux had very early on stated as one of the basic objectives of studying 'past or 
disappearing formations' that this was a 'basic requirement to judge its capacity for change in a different context'. His original essay of 1960 in which he develops the basic patterns of the domestic community, finishes with a section that briefly explores the transformations that such societies ‘usually undergo ... under the impact of market economy’ (1978a. p. 150).

The examples he goes on to use are still essentially those of the pre-colonial era: the introduction of trade in iron into a previously self-sustaining society, for instance, but he does offer the suggestion that this points the way in to a study of other processes of change 'slavery, markets, money, land tenure systems, handicrafts etc., at different moments of economic history’ (Meillassoux 1978a, p. 153). In a similar vein, Dupré and Rey (1978, pp. 197-8) conclude their exploration of the 'lineage mode of production' with a brief consideration of the "Articulation of the "Traditional" and the Capitalist Modes of Production' showing the way in which the exchange (i.e. circulation) of prestige goods provided an opening for mercantile trade, then for the slave trade, and for other forms of articulation under colonialism.

Rey (1975), however, provided a much more systematic and general treatment of this 'articulation' in his long essay originally produced in 1969. Rey retraces what he sees as the key processes and stages in the transition from feudalism to capitalism, and sees them as being paralleled in the articulation of the lineage mode of production with capitalism. The essential relationship which marks the capitalist mode of production is free 'labour power' rather than capital or the property relations of private ownership of the means of production. In exploring how this transition to wage labour came about, he sees it as initiated by modifications in the feudal relations of production, in particular converting the form of ground-rent from labour-surplus to the money form. As a result of this initial link in the sphere of exchange the feudal landlords threw some tenants off the land, thereby making available a 'free' labour force, while those remaining turned to the production of wool or other cash crops to obtain money for the rent imposed on them. The opening for this transition was provided by feudal relationships. Moreover, in the first stage of this transition, there is a complementarity between the feudal and capitalist modes of production at a number of levels. But at later stages there is a transforming effect of the articulation: the development of industry destroys handicrafts and converts peasants into producers of agricultural commodities to supply industry and provide for the reproduction of labour power almost entirely through the exchange economy. Finally, capital moves into agriculture and begins to destroy peasant agriculture.

In Africa, Rey (1975, p. 49) goes on to suggest an analogous role to ground-rent and its commoditisation is played when the lineage mode of production is articulated with a capitalist mode, by bride-wealth - the key to the circulation of prestige goods and, ultimately, the labour of juniors - and its monetisation. For the most part, wage labour was generated not in the form of fully proletarianised landless former peasants separated completely from their means of production, but as slave then migrant labour. The pre-existing relationships of production remained, even though modified; in particular the payment of bride wealth, now in cash, provided the nexus whereby young men got access to the means of production, and reproduction: land, the labour of women in the fields and the home, often as migrant labour, especially in southern Africa, but elsewhere more commonly through petty commodity production. 
In this phase, then, capitalist production relied on the indigenous mode of production continuing to supply labour power without the cost of reproducing it, but also agricultural production in the colony or to feed the labour force as well as other raw materials for capitalist production in the colony or to the international market. More concretely, though, it does so 'thanks to the action of another ruling class' (Rey 1975). In the southern African case direct exploitation by elders of juniors gives way to the elders and sometimes indigenous rulers offering up their young men, earlier as slaves, later as wage labour. At the same time the elders obtain returns either as payment for slaves or in the form of cash payments by returning labour migrants. The capitalist benefits in that labour power was cheaper than if fully proletarianised because the migrant's family continued to produce its own reproduction in the domestic community. Meillassoux (1978b, p. 169) in fact generalises this pattern of labour in capitalist settler agriculture to take in commercial production by peasants, as well as the 'labour reserves'. In either case, agriculture's 'obsolete organisation is maintained as long as possible by capitalism as a means of cheap reproduction of the labour force', either by rendering up super-exploited migrant labour, or agricultural commodities at a price which does not have to meet the peasant producers' full costs of reproduction (see also Wolpe 1972, p. 434; Legassick 1974). This additional, hidden subsidy to capital Meillassoux termed 'labour rent' - a formulation which has elicited some criticism. And on this basis he generalised his arguments in his 1975 book on women by theorising imperialism as a system which develops and depends upon certain interrelationships with the domestic community: 'by preserving the domestic sector which is producing subsistence goods ... imperialism realises and further perpetuates primitive accumulation' (Meillassoux 1981, p. 97). But expounding on Rey's analysis, he goes on: “'Modes of production” are not "articulated” at a level of "class alliances” between capitalists and corrupt lineage leaders, but also are crucially within the economic sphere itself' (ibid.).

The last insight was used as the point of departure for ground-breaking analysis, using something of the elements of the discourse summarised above in the theorising by Wolpe's writings on South Africa. In the process he also offered in more general, theoretical terms 'a precise and clear meaning to the notion of articulation' with capitalism:

The relationship between the reproduction of the capitalist economy on the one hand and the reproduction of productive units organised according to pre-capitalist relations and forces of production on the other (Wolpe 1980, p. 41).

Rey himself emphasised the political dimensions in the second period of articulation where the capitalist mode of production is established and becomes dominant, but the precapitalist modes are still required to make available a growing labour force. Moreover as these needs continue to expand the collaboration of the pre-capitalist ruling class is still needed, and so too is the political power of the state (in one form or another: forced labour; taxes to general labour power or commodity production, and not least in codifying and 'reforming' land tenure). In Africa, this would correspond more or less to the colonial period: which arises from the need for an effective state apparatus. These processes, however, tend to destroy the pre-capitalist formations, though at rates that might vary greatly from one country or continent to another. For instance, in the settler colonies like Zimbabwe or South Africa where capitalist production, even in agriculture, is implanted on a large scale, there was 
usually an overwhelming use of force to separate peasants from the land and create the necessary large labour force and very rapid destruction of the pre-capitalist modes, but even there it was far from total. Indeed artificial retention of some of the property relations and the control of elders or chiefs in 'reserves' remained central to the reproduction of cheap migrant labour. Other parts of the labour force especially those resident on and dependent for their reproduction on the commercial farms were subject to a servile form of labour relations in those settler colonies. The future of these 'labour-tenants' poses a key land reform issue in countries in southern Africa. South Africa has tried, not always successfully, to protect their residence rights. In Zimbabwe, the resident labourers have lost their rights of access and often been disenfranchised in the process of land redistribution.

A final phase is envisaged in some notions of the articulation when the reproduction of cheap labour is no longer a central requirement for capital, one that may correspond to more recent trends towards famine, or a 'simple reproduction squeeze' (in Bernstein's phrase, 2001, p. 39), where the disintegration and destruction of the indigenous form gets thoroughly under way. There is a tendency among analysts and policy makers, including some who would consider themselves informed by this Marxian approach, to welcome the resultant onset of fully capitalist relations of production and reproduction (exemplified in Warren 1980; discussed in Graeber 2006, p. 66; see alternative approaches to land reform in e.g. Quan et al. 2004). It is in this context that the approach bears on current issues about land reform.

In sum, the articulation of modes of production legacy offers not a theory or model: Rey (1975, p?) proffered this (self) critique of:

the ideal that one can construct in the library, by collecting enough

documentation, the theory of this or that mode of production, and then the theory of the articulation of that mode of production with the capitalist system

But it can offer a perspective that enables one to understand the long-term dynamics of change occurring in African societies. It also gives due significance to the contribution in the processes of transformation to the indigenous 'genes' that shape the dynamics - an understanding of situations 'where there is capitalism but also what look like pre-capitalist relations of production and reproduction'. It is for this reason, the risk of losing sight of these indigenous determinants, that we see the generalised use of the term 'petty commodity production' to characterise African contexts (e.g. Bernstein) as only of limited use. The articulation approach enables one to appreciate both the indigenous and emerging determinants but does so in a view that is neither dualist nor static. What it began to do in the later 1970s was to develop a perspective that saw the interactions not as formal or economic interactions but as taking place through political alliances and contestations. In this sense it can open the way to analysis of violent conflict.

\section{Articulation as explanation of economy and state under apartheid}

Wolpe became the best known of those articulating a perspective on South African history based on an articulation model. Among other results it challenged the pervasive (and 
still held) view of the economy and society as dualistic and highlighted the systematic interconnections between white farms and African reserves, between development and impoverishment, between white privilege and black marginalisation and oppression. Wolpe's (1972) explanation of cheap labour moved away from a purely racial and ideological explanation of apartheid in South Africa, towards an understanding that racial prescriptions would be articulated in any social formation with the mode of production (Bush, Cliffe and Jansen 1984, p. 3). He conceptualised the (partial) destruction of the pre-capitalist mode of production which facilitated the flow of cheap migrant labour and the changing conditions of production and reproduction of that labour power.

Wolpe saw social relations as being structured in ways that changed through different stages. Apartheid represented one such organised restructuring, emerging in circumstances where an almost automatic reproduction of required labour flows almost automatically from the reserves is no longer the norm, where floods of labour come in, in part reflecting an impoverishment in the reserves that threatens reproduction of workers and their kinfolk. Control of this crisis by the state led to the expulsion of unwanted labour and a tighter lid on the people who were confined to what now would be 'Homelands'.

Mafeje appears to agree in rejecting dualism, in realising stages in South African history, as seeing apartheid as essentially a cheap labour system, but challenges the Wolpe model. Methodologically, his 1981 review questioned the specific conceptualisation of articulation, and also the assumption that there is but one agency, capital, at work determining the shifts within and between stages in answer to 'some inexorable logic', and seeks to bring out other social agencies and their impact. Empirically, he questioned the conception of the pre-colonial modes, and the linkages that provide the key avenues for articulation. He questioned one 'logic' - that capital will continue to demand supplies of cheap, migrant labour. He also pushed further the implication of trends towards homelands becoming more dumping grounds than sites for subsidising labour: 'in recent years ... the reserves [are where people go] not to reproduce labour power but to perish' (emphasis added, Mafeje 1981, p. 134). In this last regard, as also in conceptualising the pre-colonial modes, Mafeje brought in the work of Meillassoux and other French Marxist anthropologists, even referencing an unpublished report that presaged the hardly more available report that Meillassoux (1982) was to write up for FAO. It is possible to see the 1981 review with its brief but forceful engagement with Wolpe's conception as a prelude to an enriching discourse between these and other analysts, and one that never gets thoroughly played out.

\section{The spatial dynamics of migrant labour}

An overlapping model of migrant labour that can be understood in the context of articulation theory shows that there is a separation of the cost of maintenance - the day to day subsistence of workers, from renewal - the vacancies created by their departure or by expansion of the labour force. The locations of maintenance and renewal, and the separation of institutions mediating these processes, are separated geographically but they remain interdependent as the migrant circulates between work and home (Burawoy 1976; Benya 2015). 
This circulation is the outcome of primary accumulation, a process dominated by nonmarket mechanisms, which sees a widening gap between productivity in the capitalist and non-capitalist sectors. Subsequently, producers in the latter sector are prepared to sell their labour-time at the wage rate determined by the capitalist sector. Hence in postwar Rhodesia, the level of wages was fixed such that subsistence covered only the worker, while the home economy would provide for retirement, sickness or unemployment (Arrighi 1970, pp. 222223). By extension, Amin (1995, pp. 37-38) argues that the region of departure experiences a net loss and migrants' labour ultimately benefits the host society, creating, for example, GDP losses in West Africa's interior countries, and gains in the coastal areas. Even an opposing perspective, that migrant labour (also) encourages development in sending regions, makes it clear that the winners of labour migration are large investors and employers (Reitzes 2000, p. 13).

The separation but interdependence of economies can intensify if a national border divides them because the migrant lacks citizenship rights (which encompass political and economic bargaining power), but these cheap labour dynamics are also sustained in internal migration patterns, such as those between the Eastern Cape and Marikana (Benya 2015, p. 547). The debate that emerged over Marikana's labour system even indicates that the separation of maintenance and renewal costs does not require significant distance, nor must the greatest proportion of workers be migrants to lower the costs of labour-power in general and reproduce the underlying characteristics of the migrant labour system.

South Africa had significantly domesticated its mine labour force in the 1970s, largely to prevent a crisis of dependence on increasingly autonomous foreign sources. While the total number of migrant workers on the mines fell to less than half, strongly affecting internal areas like Eastern Cape, the 1990s saw an increase in sub-contracting of jobs in mining, to companies that hired workers from Mozambique and Lesotho. Between 1987 and 2001, the proportion of Mozambicans in the workforce increased from 10\% to 25\% (Crush and Williams 2010, pp. 9-10; Crush 2011, p. 14; de Vletter 1994). Lesotho had around $40 \%$ of the male Basotho labour force employed in South Africa. Border restrictions eased between the countries after apartheid and long-running contract workers were offered permanent residence (which few took); while mine work could no longer be found automatically (Sechaba Consultants 1997, p. 1). After 2000, the rising price of gold led to renewed expansion on the gold mines, with an increase in workers from within South Africa's borders and a decrease in foreign miners from $60 \%$ of the workforce at the end of the 1990 s to $30 \%$ today (Forrest 2013). Yet 'local' workers constitute any of those who live within the province, and may live more than $400 \mathrm{~km}$ away.

The model of men leaving their families behind for periods of time is also one that needs interrogation. Ferguson (1990, pp. 395-6) noted that mine companies in the Zambian Copperbelt encouraged the presence of women and families from the beginning, for example with a 'permanent black town adjacent to the mine' in Bwana Mkubwa. Benya (2015, p. 552) shows the separateness but, of course, interdependence of the informal settlement in Wonderkop, less than 400 metres from the mineshafts in Marikana. From here, 'town women' maintain and reproduce the labour force on a daily basis; while 'country wives' renew the labour force in areas of origin, including the Eastern Cape, Lesotho and Mozambique. Compared with Wonderkop’s formal settlement Emzini, which has running 
water, electricity and a tarred road, the informal part known as Enkaneni resembles former apartheid townships - a centre of labour reproduction in a social formation which lacks, however, running water, electricity, decent housing, healthcare and sanitation.

\section{Migrant labour and the state}

For the reasons considered above, the cost of reproduction of labour power is diminished in a system of cheap labour, but Burawoy (1976, p. 1055) asks more precisely: cheap for whom? He clarifies that the cheapness refers not to the cost of hiring a migrant worker compared to a domestic one, but instead the cost of the system as a whole, a complex question, considering the conjectural nature of Africa's regional labour systems. The state covers the majority of costs of organising migrant labour, while industry finds this system cheaper than other systems of labour.

The state occupies a central role in this relationship between labour and capital, taking 'responsibility for that part of its value which capitalists do not directly remunerate' (de Brunhoff 1978, p. 19). The concern from a political economy perspective is what the state does, rather than what it is. Drawing on the experience of post-independence Zimbabwe, Hammar (2008, p. 429) questions 'who or what constitutes "the state" at a particular historical conjecture; what competing interests and projects of control, accumulation, development or exclusion are at stake; what forms and spaces of uncertainty, violence and displacement these generate and with what effects'. In this domain, ideology becomes important, constructing alienation of the migrant worker and masking the class structure with racial perspectives (Burawoy 1976, p. 1061; Goldberg 2009).

De Brunhoff (1978, pp. 19-27) argued that the institutions performing these complementary functions do not however work primarily through ideology or violence; rather, they create an environment for capitalist exploitation to develop and function, reflecting its inability to function without this assistance. These institutions are wide-ranging in time and space, incorporating systems of poor relief and welfare as well as those engaged in repression, whilst ultimately maintaining insecurity and exploitation through maintaining a site of class confrontation. Welfare and social security systems are not linear or static, instead growing and contracting as an outcome of relations of social power. Here it is important to consider the influence of neo-liberalism as a particular mode of exploitation and social domination based on the 'systematic use of state power to impose, under the ideological veil of non-intervention, a hegemonic project of recomposition of the rule of capital in each area of social life' (Saad-Filho 2010, p. 100, emphasis added). This recomposition constitutes the expansion of financial frontiers into new terrains, creating profit from labour reserves to the extent that the significance of aggregate demand to capitalist accumulation diminishes; new markets are constructed out of underdevelopment, underemployment and indebtedness as well as the labour-power that emerges. The state at the national level and through suprastate institutions and processes such as the European Union or the West African Economic and Monetary Union sustains an increasingly active separation of these economic and political processes in policy and discourse. There has been little consideration of 'irregular' migrations 
to Europe as a labour regime, but Castles (2006, p. 28; Cross 2013, p. 86) shows how undocumented workers, such as those surviving a high-risk voyage, meet particular EU labour demands for which there is no official provision. This creates:

... the great hypocrisy of modern migration policy ... the systematic use of undocumented migrant workers, who are denied many of the rights laid down in the human rights instruments and labour conventions endorsed by these same countries.

If we are to make comparisons between this form of migrant labour and the modelling offered by Wolpe and Mafeje in their understanding of apartheid labour - which also became an 'unwanted flood' that needed to be controlled - there is clear explanatory value in a perspective that considers the dialectic of migrant labour and social formations along with the mechanisms of reproduction of this labour, rather than the fragmented approaches that prevail.

\section{Social reproduction is external to the labour-capital relationship}

The final level of analysis to consider is the household, which is based on an organic composition between members, level of production and consumption. The commoditisation of land and labour, combined with the privatisation of social provisioning through financialisation and the proliferation of public-private partnerships in development, has led to an emphasis on two aspects of social reproduction in contemporary political economy, beyond the biological reproduction of the species and the conditions of motherhood. The first, as discussed earlier, concerns the reproduction of the labour force, which incorporates subsistence, education and training; and second, there is growing interest in the reproduction and provisioning of caring needs that 'may be wholly privatised within families and kinship networks or socialised to some degree through state supports' (Bakker 2007, p. 541). Bakker (ibid., p. 545) goes on to explain that the privatisation of the governance of social reproduction increases 'the range, depth and scope of socio-economic exploitation in global capitalism amid wider conditions of primitive accumulation', or what has also been termed the new enclosures. Today's IFI-led development discourse places the onus on migrants to develop their regions by integrating themselves and their households in the global financial structure, a process that creates new forms of profit and more capitalist winners out of continuing impoverishment (Cross 2015).

From this understanding, the 'left behind' are core to the labour migration process, with gender relations determining the flows of migration and their outcomes in the household, whilst also underpinning forms of activism and resistance (Bouilly 2016; Benya 2015). The platinum industry in South Africa evolved out of the political economy of gold, but with differences in labour recruitment and wage negotiation, such as the absence of a centralised bargaining body and, instead, forms of local collective action (Capps 2015, p.499). Herein, women have created surplus value in Marikana through their unpaid work and have also played a key role in the strikes at different levels of organisation, have attended the subsequent hearings and have sustained households through stokvels (a community 
saving scheme, Benya 2015, p. 555-6). In West Africa, Bouilly’s (2015) study equally emphasises generational and gendered relations of productive and reproductive labour (see also Whitehead 2002, p. 576), which can clearly be linked back to Meillassoux's explanation of the connections between market and non-market economies and the ways that labour and the system as a whole are reproduced. Buggenhagen’s (2012) ethnography of Muslim families in Senegal also identifies connections between shifts in social production, the constitution of households, and changing forms of value in global capitalism. While there is a general feminisation trend in migration globally, it continues to be a gendered process, with 99 percent of miners being male in South Africa, yet as shown above, migrant labour in mines has declined and female migrant labour covers a more diverse range of occupations including domestic work, trade and informal sector employment. Zimbabwe's migrant labour force is over $40 \%$ female, while Lesotho is a distant second at $16 \%$ (Dodson et al. 2008, pp. 3-4). In West African patterns, women, more typically involved in commerce, and elders have joined younger unmarried men in migrant labour flows. This is a reflection of deepening poverty and political crisis (Crush and Williams 2010, pp. 21-22; Adepoju 2005, p. 2).

\section{Conclusion}

This article concludes a long-running research collaboration that sought agendas and methods for a contemporary political economy understanding of migration and labour mobility in West and Southern Africa. The broad continuities in the regional patterns of migration identified by Amin (Amin and Bush 2014), as a starting point for seeing their diversity, sustain his argument that capitalism is not a linear process leading towards a universalised type of industrialisation. We raised the importance, in turn, of incorporating theoretical explanations of the connections, rather than dualism, between sending regions and sites of migrant labour, not only in terms of the social, economic and cultural transfers between migrants and their sending community, but also in explaining their economic interdependence in a system of cheap labour. The changing configuration of the state in relation to labour and capital and, on a different scale, an assessment of the changing relationship between capital and social reproduction, have informed this political economy framework.

To consider such dynamics more closely, the modes of production discourse has faced controversies and is theoretically underdeveloped, but it offers a conception of social production that seeks to explain the complexity of social formations in relation to a contingent capitalism. The disappearance of these debates in the 1990s has, on the other hand, been associated with a widespread naturalisation of capitalism in social research (Graeber 2006, pp. 61-62). Without modes of production, the only social formation is capitalism. A return to the discourse highlights the continuing relevance of situations where capitalism exists alongside non-capitalist relations of production and reproduction, which appear repeatedly in empirical work in different parts of Africa and elsewhere. These are not just 'pre-capitalist' but may have a very different trajectory. In this sense, Meillassoux's work 
presents a point of departure for contextualising and interpreting anthropological fieldwork, allowing the analysis of changing but specific social formations.

As well as regrets for an opportunity missed, Cliffe (2011, pp. 8-9) argued that contemporary scholarship could accept to meet two challenges in turning back but then fastforwarding those old debates, that remained 'preliminary'. First, is it beyond the scope of ingenuity, and of genuinely collaborative work among scholars (often so hard to deliver), to generate an improved Mafeje/Wolpe or Wolpe/Mafeje model that synthesises their efforts, bringing on board the improvements in conceptualisation and of knowledge made by Mafeje and the many later scholars? A second task would be to adapt the insights of Mafeje and Meillassoux as the basis for understanding the roots and nature of 'poverty' (or rather impoverishment), malnutrition, inequality, social breakdown and 'marginalisation', which so preoccupy societies in Southern and West Africa today but where effective counters to these symptoms remain elusive - maybe in part because their conceptualisation has also been inadequate?

\section{Bibliographic note}

Adepoju, A. 2005. 'Migration in West Africa'. Lagos: Global Commission on International Migration.

Amin, S. 1972. 'Underdevelopment and Dependence in Black Africa - Origins and Contemporary Forms’. Journal of Modern African Studies, 10 (4): 503-24.

Amin, S. 1995. 'Migrations in Contemporary Africa: A Retrospective View', in J. Baker and T. A. Aida (eds.) The Migration Experience in Africa. Uppsala, Sweden: Nordiska Afrikainstitutet: 29-40.

Amin, S. and R. Bush. 2014. 'An interview with Samir Amin'. Review of African Political Economy, 41 (S1): S108-S114.

Arrighi, G. 1970. 'A Study of the Proletarianization of the African Peasantry in Rhodesia'. Journal of Development Studies, 6 (3): 197-234 .

Bakker, I. 2007. Social Reproduction and the Constitution of a Gendered Political Economy. New Political Economy, 12:4, 541-556.

Baylies, C. and Wright, C. 1993. 'Female Labour in the Textile and Clothing Industry of Lesotho', African Affairs, 92 (369): 577-591.

Benya, A. 2015. The invisible hands: women in Marikana. Review of African Political Economy. 42 (146), 545-560.

Bernstein, H. 2001. 'The Peasantry' in Global Capitalism: Who, Where and Why?', Socialist Register, Vol. 37, 25-51.

Bolt, M. 2015. Zimbabwe's Migrants and South Africa's Border Farms: the roots of impermanence. Cambridge: Cambridge University Press.

Buggenhagen, B. 2012. Muslim Families in Global Senegal: Money Takes Care of Shame, Bloomington: Indiana University Press.

Burawoy, M. 1976. 'The Functions and Reproductions of Migrant Labour: Comparative Material from Southern Africa and the United States'. American Journal of Sociology, 1050-1087. 
Bush, R., L. Cliffe and V. Jansen. 1984. 'The Crisis in the Reproduction of the Cheap Labour Economies of Southern Africa'. Presented at the Review of African Political Economy Conference on the World Recession and Crisis in Africa, $29^{\text {th }}$ and $30^{\text {th }}$ September, University of Keele.

Capps, G. 2015. Labour in the time of Platinum. Review of African Political Economy. 42 (146), 497-507.

Cliffe, L. 2011. 'The Legacy of the Modes of Production Discourse and Contemporary Land Reform Issues in Southern Africa'. Unpublished paper for Festschrift in honour of Archie Mafeje, University of Cape Town, 23-24 May.

Coquery-Vidrovitch, C. 1985. 'Réflexions d'historienne'. Canadian Journal of African Studies/ Revue Canadienne des Études Africaines. 19 (1): 23-29

Cross, H. 2013. Migrants, Borders and Global Capitalism. West African labour mobility and EU borders. London: Routledge.

Cross, H. 2015. Finance, Development, and Remittances: Extending the Scale of Accumulation in Migrant Labour Regimes, Globalizations, 12:3, 305-321

Crush, J. 2011. Complex Movements, Confused Responses: Labour Migration in South Africa. SAMP Policy Brief No. 25. Cape Town: Southern African Migration Programme.

Crush, J. and V. Williams. 2010. Labour Migration Trends and Policies in Southern Africa. SAMP Policy Brief No. 23. Cape Town: Southern African Migration Programme.

De Brunhoff, S. 1978. The State, Capital and Economic Policy. London: Pluto Press.

Dodson, B. et al. 2008. 'Gender, Migration and Remittances in Southern Africa'. Migration

Policy Series No. 49, Cape Town: Southern African Migration Project.

Dupré, G. and Rey, P. P. 1978. 'Reflections on the Relevance of a Theory of the History of Exchange’. In: D. Seddon (ed.) Relations of Production: Marxist Approaches to Economic Anthropology. Frank Cass Publications: London, 171-208.

Fall, A.S. and Cissé, R. 2007. 'Migrations internationales et pauvreté en Afrique de l'ouest'. Working Paper No. 5. Manchester: Chronic Poverty Research Centre.

Ferguson, J. 1990. 'Mobile Workers, Modernist Narratives: A Critique of the Historiography of Transition on the Zambian Copperbelt [Part One]'. Journal of Southern African Studies, 16 (3): 385-412.

Forrest, K. 2013. 'Marikana was not just about migrant labour'. Mail and Guardian, 13 September.

Freund, B. 1985. 'The Modes of Production Debate in African Studies'. Canadian Journal of African Studies/ Revue Canadienne des Études Africaines. 19 (1): 23-29.

Goldberg, D. T. 2009. The Threat of Race: Reflections on Racial Neoliberalism. Oxford: Blackwell Publishing.

Graeber, D. 2006. 'Turning Modes of Production Inside Out: Or, Why Capitalism is a Transformation of Slavery', Critique of Anthropology, 26 (1): 61-85.

Devillard, A., Bacchi, A. and Noack, M. 2015. 'A Survey on Migration Policies in West Africa’. Vienna and Dakar: International Centre for Migration Policy Development (ICPMD) and International Organisation for Migration (IOM).

De Vletter, F. 1994. The Implications of Changing Migration Patterns in Southern Africa. OCDE/GD(94)5. Paris: OECD. 
Hammar, A. 2008. 'In the name of sovereignty: Displacement and state making in postindependence Zimbabwe’. Journal of Contemporary African Studies, 26 (4): 417-434.

Klein, M. 1985. 'The Use of Mode of Production in Historical Analysis'. Canadian Journal of African Studies / Revue Canadienne des Études Africaines, 19 (1): 9-12.

Legassick, M. 1974. 'South Africa: capital accumulation and violence'. Economy and Society, 3 (3): 253-291.

Mafeje, A. 1981. 'On the Articulation of Modes of Production: Review Article'. Journal of Southern African Studies, 8 (1): 123-138.

Meillassoux, C. 1978a. “'The Economy' in Agricultural Self-Sustaining Societies: a Preliminary Analysis'. In: D. Seddon (ed.) Relations of Production: Marxist Approaches to Economic Anthropology. Frank Cass Publications: London, 127-158.

Meillassoux, C. 1978b (1960). 'The Social Organisation of the Peasantry: The Economic Basis of Kinship’. In: D. Seddon (ed.) Relations of Production: Marxist Approaches to Economic Anthropology. Frank Cass Publications: London, 159 - 170.

Meillassoux, C. 1981. Maidens, Meal and Money: Capitalism and the Domestic Community. Cambridge: Cambridge University Press.

Meillassoux, C. 1982. Apartheid, Poverty and Malnutrition. FAO Economic and Social Development Paper 24, Rome: Food and Agricultural Organisation of the UN.

O’Laughlin, B. 1999. 'In Defence of the Household: Marx, Gender and the Utilitarian Impasse'. Working Paper 289. The Hague: Institute for Social Studies.

Potts, D. 2010. Circular Migration in Zimbabwe and Contemporary Sub-Saharan Africa. Rochester, NY: James Currey.

Quan, J. Tan, S.F. and Toulmin, C. (eds.) Land in Africa: Market Asset or Secure Livelihood? Proceedings and summary of conclusions from the Land in Africa Conference, London: IIED, Natural Resources Institute and Royal African Society. 89 November.

Reitzes, M. 2000. Regionalizing International Migration: Lessons for SADC. Migration Policy Brief No. 11. Cape Town: Southern African Migration Project.

Rey, P. P. 1975. "The Lineage Mode of Production." Critique of Anthropology, 3: 27-79. Saad-Filho, A. 2007. Monetary policy in the neo-liberal transition: a political economy critique of Keynesianism, monetarism and inflation targeting. In: Albritton, R., Jessop, B. and Westra, R. (eds.) Political Economy and Global Capitalism. London: Anthem Press, p. 89-119.

Sebecha Consultants. 1997. 'Riding the Tiger: Lesotho Miners and Permanent Residence in South Africa'. Cape Town: Institute for Democracy in South Africa, South African Migration Project.

Terray, E. (translated by Anne Bailey). 1984. 'Classes and Class Consciousness in the Abron Kingdom of Gyaman’, in M. Bloch (ed.) Marxist Analyses and Social Anthropology. London and New York: Tavistock Publications. 85-136.

Warren, B. 1980. Imperialism: Pioneer of Capitalism. London: NLB and Verso.

Whitehead, A. 2002. 'Tracking Livelihood Change: Theoretical, Methodological and Empirical Perspectives from North-East Ghana'. Journal of Southern African Studies, 28:3, 575-598. 
Wolpe, H. 1972. 'Capitalism and cheap labour-power in South Africa: from segregation to apartheid'. Economy and Society, 1 (4): 425-456.

Wolpe, H. 1980. 'Introduction'. In Wolpe, H. (ed.). The Articulation of Modes of Production: Essays from Economy and Society. London: Routledge \& Kegan Paul, pp. 1-43. 